\title{
Disruptive colonial boundaries and attempts to resolve land/boundary disputes in the Grasslands of Bamenda, Cameroon
}

\section{Emmanuel M. Mbah*}

\begin{abstract}
The 1990s ushered in an unprecedented wave of violent land/boundary disputes between village-groups in the Grasslands of Bamenda, North-West Province of Cameroon, on a scale that had never been witnessed before. Widespread hardship, introduced by the prevailing economic crisis was blamed for these disputes. But on closer examination it became clear that land/boundary disputes in the region have their roots in European colonialism, and derive largely from administrative policies that were disruptive on inter-village boundaries. Despite the efforts of British colonial authorities at resolving these disputes before the close of the colonial era, they have persisted because post-colonial administrations in Cameroon have failed to judiciously address them.
\end{abstract}

* Dr Emmanuel Mbah is Assistant Professor of History at the City University of New York, Staten Island, New York. 


\section{Introduction}

From the onset of European colonial rule in Cameroon in 1885 the Bamenda region has been the subject of recurrent land/boundary disputes between villages. When Germany annexed Cameroon in 1885 it proceeded to administer Bamenda with the assistance of a few favoured groups. This political dispensation, which aimed at facilitating German colonial rule, had devastating effects on village-groups. When Germany was defeated during the First World War, Cameroon was provisionally partitioned between Britain and France, following an unsuccessful Anglo-French condominium. That partition was confirmed in 1919 by the Milner-Simon Agreement (Niba 2007). Southern Cameroon was administered by the British as a League of Nations mandate, and after World War Two as a United Nations trust territory. When the British took over their share of Cameroon, which included the Grasslands of Bamenda, they were confounded with numerous land/boundary-related disturbances between village-groups. Their first impulse was to suppress these by maintaining the status quo inherited from the Germans. Before long, some British administrators began to realise the injustices embedded in some of the village boundaries bequeathed by their predecessor, but not before creating problems of their own.

This essay examines the administrative dynamics of German and later British colonial rule that conspired to create or heighten land/boundary disputes in the region, as well as attempts made by the British and post-colonial administrations at resolving them. My argument here is two-fold: First, I contend that unsound colonial administrative and economic policies were the result of boundary disputes in the region. Second, I argue that despite the disruptiveness of colonial policies on boundaries in the region, the British had a more practical approach in resolving them than current post-colonial administrations. This study is important in view of the negative effects of land/boundary disputes on development in Cameroon in particular, and in Africa in general. 


\section{Attempts to resolve land/boundary disputes in Bamenda, Cameroon}

\section{Ethno-tribal favouritism}

German administrative policy in the Grasslands of Bamenda was designed to bolster favoured village-groups that collaborated with German colonial exploitation, while those that did not were subjugated and placed under the suzerainty of friendlier ones as vassals (Chilver and Kaberry 1968). This policy hinged on an alliance with the village of Bali-Nyonga, and was cemented by a treaty of protection signed on 23 August 1891 between Dr. Eugen Zintgraff, representing the German Government, and chief Galega I, representing the people of Bali-Nyonga. The treaty offered an opportunity for German colonial authorities to combine forces with Bali-Nyonga in subjugating and exploiting village-groups in the region (Chilver 1966:30-31). In exchange for surrendering his powers, Galega had the advantage of control over all Grassland villages. Attempts by Bali-Nyonga to implement the provisions of the treaty would become the source of recurrent conflict with neighbouring villages because the former used the treaty to encroach on land that belonged to the latter.

From 1902 to 1915 the German colonial government in Cameroon recognised Bali-Nyonga suzerainty over a large area in the region (File No. 9570 Qf/b (1) 1943:11). For this recognition, Bali-Nyonga was to assist the Germans in subduing surrounding village-groups. Zintgraff had realised the impossibility of 6000 Bali-Nyonga soldiers subjugating more than 15000 soldiers of those neighbouring villages. For this reason, 1000 rifles were provided to Galega, and Bali-Nyonga soldiers were drilled on the act of modern warfare (Chilver 1966:8). A German military station was set up at Bali-Nyonga, and on 15 June 1905 Galega was given a list of 33 villages under his control (Hunt 1925:23).

German colonial support for Bali-Nyonga and a small number of favoured village-groups resulted in the demarcation of arbitrary boundaries reflecting that dispensation. This was the case between Bali-Nyonga and surrounding Widikum ethnic villages. To be fair, however, hostilities between the two had commenced long before the establishment of German rule. Before this time, Bali-Nyonga had conquered part of its present territory from some Widikum villages, although the degree of conquest and the amount of land taken is 


\section{Emmanuel M. Mbah}

debatable. An uneasy peace and some degree of co-existence between BaliNyonga and these groups prevailed just before German rule (File No. 9570 Qf/b (1) 1943:11). With German support, Bali-Nyonga was able to maintain a strong hold over Widikum village-groups, depriving them of some of their ancestral land.

The colonial policy of propping up friendly ethno-tribal groups against less friendly ones was not unique to the Germans. In the Ivory Coast the French pursued an ethnic policy of assigning groups to distinct territorial confines, using 'ethnic maps to better identify them, better implicate them and if necessary thrust guilt upon them' (Gonnin 1998:153). But the French were unsuccessful because their colonial administration 'was never able to subjugate one ethnic group to the extent of being able to pitch it against the others' (Gonnin 1998:164). During the early years of British colonial rule in Nigeria, administrators also made use of the policy of divide and rule, as evidenced by their role in the land conflict between Aguleri and Umuleri, both Igbo ethnic communities of south-eastern Nigeria. Here, the British intensified the already heightened precolonial ethnic/land conflict between these groups by supporting one over the other. In the 1930s, for example, Captain O'Connor, the District Officer (DO) in the region, exacerbated the situation by encouraging subjects of Umuleri to lay claim over the entire contested territory of Otuocha. By supporting Umuleri against Aguleri, the fairness of the British legal system was questioned as subjects of Aguleri lost faith in it. As Ekeh contends, 'it is this lack of faith, partly carried over from the colonial state, that accounts for the inability of the post-colonial state to resolve the problem' (Eheh 1999:359-360).

In the Bamenda region, Widikum ethnic villages refused to acquiesce in German policies that placed them under Bali-Nyonga, and some rebelled by proclaiming autonomy. These villages were razed by a joint Bali-Nyonga-German force and their subjects were rounded up and taken to specific locations inside BaliNyonga. Many ended up as labourers in German plantations on the coast while their land was taken over by Bali-Nyonga subjects. The two village-groups most affected by this were Ngyen-Mbo and Ngyen-Muwa (File No. 4848 Qf/b (3) 1933:32). While these two persistently refused to accept the position of vassal to 


\section{Attempts to resolve land/boundary disputes in Bamenda, Cameroon}

Bali-Nyonga, the initial British response was to maintain the set-up established by German authorities (File No. 4848 Qf/b (3) 1933:115).

In an attempt to take advantage of the transition from German to British rule, five Widikum villages again rebelled by seceding from Bali-Nyonga. But when the villages of Ngyen-Mbo and Ngyen-Muwa who inhabited land adjourning Bali-Nyonga attempted to secede for the second time, their newly constructed huts were again destroyed by the British in 1921 and their subjects were rounded up again and herded to Bali-Nyonga. The British defended their action by arguing that 'the land they were building on was right on the Bali doorstep and within the limits set by the Germans to Bali land' (File No. 4848 Qf/b (3) 1933:115). ${ }^{1}$ British position, as upheld by W.E. Hunt, DO for Bamenda Division, and confirmed by the Resident, Cameroons Province, was that Bali-Nyonga had suzerainty over the land inhabited by Ngyen-Mbo and Ngyen-Muwa (File No. 734 Qf/b (2) 1943:2).

The bone of contention between Bali-Nyonga and Ngyen-Mbo was the piece of land on which the town of Bali-Nyonga is located. The Ngyen-Mbo community claimed that it was unjustly seized from them and handed over to Bali-Nyonga by German authorities, and that they therefore wished to return to it. They argued that they could not be separated from their ancestral shrines and places of sacrifice/worship on the site. Their pleas could not be entertained by the British in view of the number of years that Bali-Nyonga had occupied the territory in question. Ngyen-Muwa, on the other hand, realised the futility of questioning British authorities over the issue of Bali-Nyonga suzerainty. Its subjects did not, however, abandon all claims to portions of territory recognised by the British as belonging to Bali-Nyonga (File No. 4848 Qf/b (3) 1933:58-61). These land/boundary disputes between Bali-Nyonga and Widikum ethnic groups have persisted to this day. Had the Germans not instituted their policy of ethnic favouritism, upheld to some degree by the British, there would have been less land disputes in the region.

1 British colonial authorities were aware that Bali-Nyonga's claim to vast territory in the region could not have rested entirely on conquest, but was prompted by the Germans. 


\section{Disruptive boundary demarcations/delineations}

Other land/boundary-related disputes arose when the British decided to demarcate boundaries to resolve the confusion created by the Germans. The demarcations of boundaries between Bali-Nyonga and Guzang, and Mankon and Nsongwa, are examples worth examining.

The conflict between Bali-Nyonga and Guzang stemmed from a 1928 boundary demarcation by British administrator, J.S. Smith, Assistant District Officer (ADO), to resolve a German-created boundary dispute between the two. The boundary demarcated by Smith was not satisfactory to the Guzang community who petitioned the administration for an adjustment, claiming that part of its land containing raffia groves, fruit trees, ancient places of sacrifices/worship, graves, and traditional monuments had been left on the Bali-Nyonga side of the boundary, and that Smith failed to inspect the entire stretch of territory, preferring to stand on the road-side and point to where he thought the boundary was supposed to be (File No. 9570 Qf/b (1) 1943:2).

In a series of petitions the village of Guzang requested British administrators to review Smith's decision (File No. 9570 Qf/b (1) 1943:15). This was eventually done by the Resident who observed that Guzang had good reasons for making its claim. He remarked that the decision reached by Smith was in some respects flawed, and that in so far as the decision regarding the conflict was an administrative one, Guzang had the right to pursue legal action (File No. 9570 Qf/b (1) 1943:5-8). In haste to demarcate that boundary, Smith failed to diligently survey the disputed territory and carved out a boundary that was in essence disruptive. Despite the Resident's reservations, the Smith boundary was maintained, and has remained a source of continuous bickering between both villages.

The conflict between Mankon and Nsongwa, another case of the disruptive colonial boundary, began in 1927 when British authorities demarcated a boundary between them to resolve another dispute that was created by the Germans (Fanso 1982:41). ${ }^{2}$ Before German colonial rule, Mankon was the

2 Both villages belong to the Ngemba clan of the Widikum ethnic group. 


\section{Attempts to resolve land/boundary disputes in Bamenda, Cameroon}

largest and most organised chiefdom around the Bamenda Station. Nsongwa, on the other hand, was a small Ngemba community that had sought protection from Mankon, settling on part of its territory during the Bali Chamba raids. The chief of Mankon subsequently granted Nsongwa permission to relocate to a much larger area of his territory to accommodate its farming and hunting needs (Fanso 1982:42).

During the process of carving out tax and 'corvee' units, German colonial authorities altered the Mankon-Nsongwa equation by recognising Nsongwa as an independent village and its leader as chief. This was done as part punishment of Mankon for its contempt of German rule and for fighting on the side of Bafut against a combined German/Bali-Nyonga contingent in 1891 (Niba 2007). Administrative recognition served as a boost to Nsongwa, who now claimed the existence of a boundary with Mankon (Fanso 1982:42). The dispute was intensified when British administrators unsatisfactorily demarcated this boundary in 1927 .

The disagreement between Mankon and Nsongwa boiled down to a raffia grove, some farms, and a few isolated huts, which the latter claimed had been left on the former's side of the 1927 boundary. While both villages agreed that they had jointly exploited the contested land previously, they disagreed on the exact location of the boundary as established by the 1927 demarcation. Mankon argued that the contested land had always been part of its territory. Nsongwa, on the other hand, maintained that it would not accept any boundary that deprived its subjects of their raffia grove and houses, arguing that it was unfair and unjust for the District Officer's boundary to allocate such property to Mankon or to ask them to accept compensation for it' (File No. 2341 Qf/b (1) 1938:7; Fanso 1982:46). Both sides stuck tenaciously to their claims, rendering a compromise difficult.

\section{Colonial tax policies}

The taxation policies of the Germans, and later the British colonial administration, also introduced boundary disputes in the region. German authorities drew boundaries based on demographic figures as well as on the 


\section{Emmanuel M. Mbah}

amount of anticipated tax revenue. Villages unable to collect the required sums in taxes lost their suzerainty and were placed under friendlier or financially viable ones. In the case of villages placed under Bali-Nyonga, its chief received a $10 \%$ proceed from all taxes collected, as stipulated by Articles four and five of the Bali-Nyonga-German Treaty (Hunt 1925:13). The tax collectors, mostly Bali-Nyonga adult males, used tax drive opportunities to perpetuate abuses on subject villages. Individuals who could not meet tax obligations were sometimes herded to Bali-Nyonga, to be transferred to coastal plantations as labourers. In 1905 and 1907, for example, subjects of some Widikum villages were rounded up and taken to Bali-Nyonga because they were unable to pay taxes. Some of their villages were razed and part of their land was seized by Bali-Nyonga, and these incidents remained a source of conflict (File No. Ab 5 1925:13; Mbah 1994:37-40). Bali-Nyonga decided to settle immigrants from French Cameroon on part of the confiscated land, on the fringes of its borders. Some of these immigrant communities, such as the Bawock village-group are now contesting boundaries with Bali-Nyonga (Nkematabong 2007).

Colonial authorities were squeamish when proceeds from taxation were inaccurate and did not hesitate punishing whole villages for tax default. An attempt to punish the village head of Babadji for failing to account for tax money was in part responsible for a boundary conflict that ensued in 1930 between Babadji and Okoremanjang in the Wum area. When the DO for Bamenda Division came to delineate a boundary between both village-groups, an occasion that was also used to audit tax records, he was infuriated at the Babadjis for failing to account for all collected tax money. In the ensuing land delineation he purposefully left part of Babadji territory on the Okoremanjang side of the demarcated boundary, thereby creating a land/boundary dispute where none existed before (File No. 1130 Qf/f (1) 1950:10).

\section{Colonialism and communal land}

The notion that land could be communal property, jointly exploited by many villages was alien to European colonisers. In traditional Africa, all land was the property of some group or community; the concept of wasteland or no man's 


\section{Attempts to resolve land/boundary disputes in Bamenda, Cameroon}

land as applied in Europe was absent. Collective ownership over communal land ensured harmony between village-groups exploiting it. As communal property, such land was collectively protected from aggressors (Fanso 1982:12-13). With little understanding of the function of communal land colonial authorities destroyed its existence with unwarranted demarcations, instilling a sense of private ownership among village-groups who previously exploited land in common.

Of course, the German policy of propping up friendlier communities was largely responsible for destroying the concept of communal land in the region. As a result of the partnership between the Germans and Bali-Nyonga, whole communities either fled their original sites or were forced to move to different locations. In the wake of a resurgence of land/boundary conflict during the transitional period between German and British colonial rule, the British, due to ignorance, complicated the issue by either demarcating such land, or by assigning it exclusively to one party. Disagreements over ownership of previous communal land were to a greater extent, the source of conflicts between Akum, Nsongwa and Mbatu; Mbunjei and Guzang; and Bambili and Babanki-Tungo.

The dispute between Akum on the one hand, and Nsongwa and Mbatu on the other, began in 1917 when British administrators demarcated a boundary on land communally exploited by all three village-groups (File No. 2124 Qf/b (2) 1939:25). The conflict was given little attention until 1937 when administrators in Bamenda called for a hearing to re-examine the boundary. It was obvious from the hearings that took place on 3 March 1937 that the land in question had been jointly exploited in the past as farm and hunting grounds by all three, who had equal rights over it until British administrators demarcated a boundary between them. As the chief of Nkwen observed in 1917, the demarcation exercise marked the beginning of the dispute because it was only then that some of their subjects realised or were told that they were living on the wrong side of the boundary. Demarcation, therefore, ran parallel to their communal land use patterns (File No. 2124 Qf/b (2) 1939:10-13).

Similarly, the land/boundary dispute between the villages of Mbunjei and Guzang in the Moghamo clan area of present-day Momo Division began in 


\section{Emmanuel M. Mbah}

1920 after a boundary was demarcated between the two by British administrator G.S. Podevin. The boundary was unacceptable to either party because it was vague, unclear, and because it cut across their commonly exploitable land. Podevin's boundary introduced a dispute between these two villages over their exact territorial limits (File No. 1828 Qf/b (1) 1936:3).

Meanwhile, the boundary dispute between Bambili and Babanki-Tungo, which started in the 1930s, resulted from a British boundary demarcation that assigned territory previously exploited on a communal basis to one party (Tangwa 1993:1). ${ }^{3}$ The disruptiveness of the 1930 boundary ensued in bickering between both villages until another British administrator, Westmacot, demarcated a second boundary in 1958 (Tangwa 1993:1-2). The conflict, however, resurfaced in the 1990s when economic considerations led to varying interpretations of both the boundary of 1930 and the Westmacot boundary of 1958 (Kwai 1997). Again, this boundary was disruptive and as with other colonial boundaries, became unclear with the passage of time.

Not unrelated to taxation were other disputes over communal land resulting from a colonial decision in the late 1930s to survey and delineate/demarcate grazing zones from farmlands. This was the outcome of a British policy designed to stimulate cattle grazing, and hence taxes paid by the Bororo-Fulani graziers. The entire procedure was ill-advised; even before the demarcations proceeded, some British officials had warned that the process would not succeed if the demarcated territories were jointly exploited and, therefore, subject to claims by two or more village-groups. For example, if $\mathrm{C}=$ Bororo and $\mathrm{A}$ and $\mathrm{B}=$ agricultural clans, and $\mathrm{Z}$ is a piece of pasture land, it is not possible to grant ... rights of user over $\mathrm{Z}$ to $\mathrm{C}$, until the claims of A and B are settled' (Senior District Officer, Bamenda, 1941:51). In the Nsungli area, where 10\% of the proceeds from cattle taxes were supposed to be shared between the Bororo headman who collected the taxes $(5 \%)$, and the village community that provided the grazing land $(5 \%)$, it was difficult to decide which village-group should receive the latter $5 \%$ because of multiple disputes where a number of villages claimed ownership over a single pastureland. In the Wiya area, the demarcation exercise

3 Joseph Fover Tangwa was the technical adviser to the Governor on boundary disputes. 


\section{Attempts to resolve land/boundary disputes in Bamenda, Cameroon}

proceeded speedily until it got to the boundary between Wiya and Mfumte, where a boundary dispute had arisen precipitously over ownership of the land in question (Senior District Officer, Bamenda, 1941:51-52). Similar disputes occurred between other villages and the process was eventually abandoned, but there was no telling how much damage such demarcations had caused. Many of these colonially-imposed boundaries with their inherent potential for conflict have persisted to this day.

\section{The Anglo-French international boundary}

Finally, some land/boundary disputes were introduced during the process of demarcating the international boundary between French and British spheres in Cameroon, from 1916 to 1922. During that exercise, village-groups inhabiting the frontier were asked to decide on what side of the boundary they preferred to belong. Many were unaware of that choice and some did not take the offer seriously, believing that the international boundary was a white man's boundary and would have no effect on them (Fanso 1982:31-33). They were wrong; the demarcation introduced disputes between villages on both sides of the boundary.

This was the source of a conflict between Bafanji and Bali-Gasho after the international boundary had split the latter into two. Bali-Gasho was given the option of relocating to Bagham territory on the French side, or to Bafanji on the British side. The DO for Bamenda advised Bali-Gasho to opt for the latter course because, as he assured them, he would use his position to negotiate sufficient land for them on the British side. The advice was taken and negotiations commenced between the chiefs of Bafanji and Bali-Gasho. The parties agreed that Bafanji would abandon its original site and relocate to territory east of River Mombe-Tangwa. Bali-Gasho was to occupy the land vacated by Bafanji from the west bank of that river to the Anglo-French international boundary. River Mombe-Tangwa was to serve as their temporal boundary and Bali-Gasho made a commitment to recognise the suzerainty of the chief of Bafanji who had made the generous offer to them (File No. 22411 Qf/b (1) 1948:13).

Not long after the arrangement, Bali-Gasho stopped honouring the part of the agreement stipulating that they recognise the suzerainty of the Bafanji chief. The 


\section{Emmanuel M. Mbah}

dispute finally came into the open when after twenty years of the agreement, subjects from Bali-Gasho began crossing the river to farm, fish, hunt, and fetch firewood from the Bafanji side because of the inadequacy of the land they were resettled on. An attempt by Bafanji to repulse them in 1945 resulted in a skirmish. The chief of Bali-Gasho then took action against Bafanji in the Ndop Native Court (NC) (File No. 22411 Qf/b (1) 1948:1, 13). As the case dragged on, so did the dispute. Had it not been for the disruptive nature of the international boundary there might never have been a dispute between these villages.

\section{British solutions}

The Germans did not establish appropriate legal systems to address land/ boundary disputes in the Bamenda region. Having placed vassal villages under propped-up communities, 'it was German policy to interfere as little as possible in tribal life or in the customs that determined native conduct ... to show proper respect for native chieftains ... [and to avoid] weakening their authority over tribesmen'. ${ }^{4}$ At the beginning of their tenure in the region the British encountered many disturbances over land between villages. Before 1933 they believed that solutions to these lay in boundary demarcations using European ideals of cairns and pillars planted on demarcated boundaries. By 1933 the futility of such a policy was realised and the entire system was overhauled.

Changes as to how the British addressed boundary disputes had been under consideration as far back as 1917 when G.S. Podevin established an instructional court in Bamenda for the training of indigenous chiefs on a new NC ordinance. But by 1922 that ordinance had still not been fully implemented and it was only later that real innovations were combined with pre-existing ones in the resolution of land/boundary disputes (Chem-Langhee 1983:656). Specifically in 1933 the British introduced the Inter-Tribal Boundaries Settlement Ordinance (ITBSO), which combined NC and administrative procedures in the resolution of boundary disputes (File No. C 64 Qf/a (1) 1933:1). Under the ITBSO, NCs examined disputes at lower levels and were presided over by clan chiefs while other chiefs sat on the bench as judges. The court's president was elected each

4 As quoted in Chem-Langhee 1983:656. 


\section{Attempts to resolve land/boundary disputes in Bamenda, Cameroon}

session, although once elected he could hold office for as long as his conduct and management of affairs of the court were good (Colonial Office 1956:64).

NCs were given a hand in the resolution of land/boundary disputes because British authorities presumed, rightly, that they knew more about the history and intricacies of disputes in their Native Authority (NA) areas. In situations where one $\mathrm{NC}$ had to adjudicate a dispute between two chiefdoms belonging to two NAs, an administrative officer was supposed to sit in as president of the court, and this was stipulated by NC Ordinance order-in-council No. 19 of 1934 (File No. 2341 Qf/b (1) 1938:29). The main function of NCs was adjudication, 'the process by which in African tribes with courts, judges take and assess the evidence, examine what they regard as the facts, and come to a decision in favour of one party rather than another' (Gluckman 1965:183).

The ITBSO had an advantage in determining a boundary between two or more communities where none could prove any justifiable title under NC proceedings to the land in dispute. It was particularly useful 'where claims and counter claims to title have been dismissed or non-suited by the [NCs] or where there [was] virgin bush between two communities' (Lawrence 1950:6). The ordinance was also useful in determining boundaries between administrative units including jurisdictional limits of NAs for tax collection purposes (Lawrence 1950:6). Where the ordinance was used to demarcate a boundary between two communities but unfairly assigned the property of one party on the wrong side of the boundary, a court order was required to effect the removal of any such property (Lawrence 1950:6).

Under ITBSO provisions, administrative officers were required by law to inquire into and settle disputes between chiefdoms in the region (File No. Qf/a (1) 1964:13). A resolution could only be proclaimed after the completion of a thorough process of fact finding and collection of evidence from opposing groups (File No. 4848 Qf/b 1933:36; File No. Qf/a 1964:13). A number of considerations were taken into account by the inquiring officer before deciding the case. These included the history of the dispute, effective occupation, relative population numbers, relative amount of land held by claimant villages, relative distances 


\section{Emmanuel M. Mbah}

from area of dispute, equity, as well as considerations regarding accessibility to roads and markets (File No. 2124 Qf/b 1939:20-22, 25-29).

Some of these considerations were not sound and resulted in wasteful competition. First, it was difficult for administrators to get reliable information on the history of disputes from neighbouring chiefs who, in the most part, had stakes in them and hence, were wont to support/corroborate versions provided by allies. Second, use of the principle of effective occupation was unreasonable; for example, it compelled the village of Mbatu and Nsongwa, who were in desperate need of land, to construct houses at night on contested territory, in order to claim rights to it (File No. 2124 Qf/b 1939:9-11). Third, there were serious problems with social justice considerations especially where officers used their discretion wrongly.

The resolution of boundary disputes under the ITBSO was onerous and labourintensive. Under the ordinance, an administrator was supposed to ensure that agreement was reached between villages on either side of a boundary, 'step by step as he proceeds to settle it on the ground' (File C 64 Qf/a 1933:1). This aimed at facilitating future arbitration of disputes that had already been settled under the ITBSO, as it would be difficult to contradict such settlements (File C 64 Qf/a 1933:1). Administrative officers also reviewed cases where NCs deadlocked on judgments (Colonial Office 1956:64-65). In situations where an NC judgment was unsatisfactory to one party, that party had the right to request a review from a DO, the Resident, or the Governor, according to the level concerned. Applications for review had to be submitted not more than thirty days from the date of Judgment. A DO's decision had legal backing, but was not supposed to be affirmed by the Resident unless there were specific reasons why such affirmations should be done: 'If he [the Resident] does affirm, he loses the opportunity to vary the decision or order a further inquiry and it must be expected that a case will occur now and then that requires revision' (File C 64 Qf/a 1933:1).

To guard against injustice, administrative officers must state reasons for their judgment, once one was reached (File 22411 Qf/b (1) 1948:14). If after conducting the inquiries and reviews the respective officers were unable to reach a settlement, a Magistrate's Court assumed jurisdictional authority over 
the dispute. This happened often where disputes resulted in claims and counter claims over titles to land; or where there was controversy about the history of the dispute; or where the facts of the case produced in evidence were unclear, inconclusive, or unbelievable (File No. 4848 Qf/b 1933:36).

Claims by villages over land title did not fall under the jurisdiction of the ITBSO because that ordinance could not award title to land and, therefore, could not be used in awarding land to any village-group. Issues regarding land title and award were subject to more rigid legal scrutiny because, in most cases, title awards were irreversible. Individual rights of title to parcels of land on contested territory were also not affected by an ITBSO decision, although 'the question of title to land and individual rights to portions of the land in question [could serve as] the evidence upon which an officer inquiring under the ordinance should base his decision where to draw the boundary' (File No. 4848 Qf/b 1933:36).

The ITBSO was a powerful tool in the reduction of boundary disputes in the region. In the following section I examine the use of specific attributes of that ordinance in the resolution of the Akum-Nsongwa-Mbatu dispute. The same procedure was applied in the resolution of all land/boundary disputes in the region after 1933.

\section{Akum-Nsongwa-Mbatu land/boundary resolution}

Authority for R. Newton to hold an inquiry and settle this dispute under the ITBSO was conveyed in telegram No. 384/2124 of March 2, 1937 from the Resident. In the ensuing findings, the chief of Akum (the plaintiff) declared that the contested territory belonged to his village by virtue of ancient traditional rights. In his deposition he argued that Akum had, since pre-colonial time, been in unquestionable occupation of the contested territory, and that prior to German occupation its Latenung quarter had been permanently settled on it (File No. 2124 Qf/b (2) 1939:26). Evidence adduced by Newton disproved this claim.

Newton established in his findings that the contested territory had been unoccupied before the establishment of a German protectorate in Cameroon, 


\section{Emmanuel M. Mbah}

during which period the territory served as communal hunting ground for five different village-groups, a fact supported by the chiefs of Mankon, BamendaNkwe, Nkwen, and Mbatu, who equally claimed ancient rights of game over the territory. Newton also observed that none of these villages could have ventured into the contested territory during the period of the Bali-Nyonga raids just prior to German colonial rule. Newton also ascertained during his tour of the region that the contested territory was a considerable distance away from each of the village settlements claiming it, and that its occupation and settlement actually began only in 1916 with the establishment of British peace (File No. 2124 Qf/b (2) $1939: 20,26)$.

The claims of effective occupation advanced by the village of Akum were also discounted from evidence produced by the chiefs of Mankon, Nsongwa, Mbatu, and Bamenda-Nkwe who all claimed rights on portions of the same territory. The village of Akum, which had hitherto been pre-occupied in other land/ boundary disputes with neighbouring Santa, had little visible property on the contested territory until its Latenung quarter began settling on the territory's fringes in 1921 (File No. 2124 Qf/b (2) 1939:20-26). Before 1916 the people of Akum resided on the hilly forest below the Bamenda military station, where their chief's palace remained until 1935. This information was corroborated by the chief of Nkwen who testified that the people of Akum had been constrained to those hills by a previous boundary demarcation by Dixon (ADO) in 1934 (File No. 2124 Qf/b (2) 1939:27).

During the 1934 hearing, Dixon had reached a settlement between Akum and Mankon on parts of the contested territory but did not grant sole rights of exploitation to Akum, as claimed by its chief. That arrangement was without prejudice to future claims emanating from any other village-group over the same territory. As Dixon noted at the time, 'I made no attempt to interest myself in any disputes between Akum, Mbatu, and Nsongwa' (File No. 2124 Qf/b (2) 1939:27). While the Dixon settlement, accepted by all at the time, forestalled disturbances that could have resulted from rivalries between Mankon and Akum, it could not have granted exclusive rights to the latter, because the territory was subject to another claim involving Akum, Mbatu, and Nsongwa. Evidence was collected to the effect that Mbatu and Nsongwa had tried but failed to press on Dixon 


\section{Attempts to resolve land/boundary disputes in Bamenda, Cameroon}

to settle their own claims during the arrangements made between Akum and Mankon (File No. 2124 Qf/b (2) 1939:27-28).

It was also established during Newton's hearing, as during Dixon's previous hearing, that none of the parties could prove exclusive rights over the contested territory. Based on these findings, Newton concluded that the best way to maintain peace was by invoking social considerations in demarcating boundaries on the contested land, observing that 'a litigant seeking to oust the occupants of land must have clearly proved claims to justify the resulting disturbances and inconvenience he causes' (File No. 2124 Qf/b (2) 1939:22-28). From the evidence collected, he was convinced that the claims of Akum did not justify such action in its favour (File No. 2124 Qf/b (2) 1939:22-28).

The fact that the merits of this particular dispute were common knowledge among subjects of Ngemba, Bafut, and Bali NAs, also inspired Newton's decision. In a tour of the region in 1933 British authorities were apprised of the rivalries between Akum and Mankon over territory and hegemony in the Ngemba area; the successful coup through which the whole of the Santa area had come under Akum; and the hatred and hostility between Akum and Mbatu, stemming partly from the uncompromising/aggressive nature of the chief of Mbatu as well as from the fact that subjects of Mbatu had always sided with Mankon, the traditional enemy of Akum, in all land/boundary cases (File No. 2124 Qf/b (2) 1939:28). The one strong argument brought forward by the chief of Akum, purporting that their Latenung quarter had settled on the territory in question long before the British arrived, was dismissed by Chinda and Chebi, from Nso and Kom respectively, who, as Government Messengers versed in the history of the area in view of their numerous tours with colonial administrators, were unprejudiced because they had nothing to gain from the outcome of the dispute (File No. 2124 Qf/b (2) 1939:28).

In the final settlement, two important principles were taken into consideration effective occupation and the relative amount of land held by each party. On the first, Newton noted that houses belonging to Akum touched only the fringes of the contested territory, and were generally absent on the territory itself, whereas those of Mbatu and Nsongwa could easily be located all over the territory. In 


\section{Emmanuel M. Mbah}

his view, if ownership of the Latenung quarter by Akum was to be considered a good claim, then Mbatu and Nsongwa equally had as good a claim, since their houses linked those of Latenung quarter and had been on the territory for more than ten years prior to the 1937 inquiry (File No. 2124 Qf/b (2) 1939:28-29).

In considering the relative amount of land held by each village, Newton noted that whereas Akum had sufficient land right up to Santa, Mbatu and Nsongwa crowded together on a relatively small territory, and therefore, needed greater consideration. In retrospect, Newton realised that land shortage was largely responsible for the violent manner through which Mbatu and Nsongwa pursued land/boundary claims before the 1937 inquiry (File No. 2124 Qf/b (2) 1939:28-29).

Newton demarcated an acceptable boundary that divided the contested territory equitably between the three claimants. The chief of Akum who had initiated the claim declared after the resolution that 'for myself, no further dispute exists in this region' (File No. 2124 Qf/b (2) 1939:29). A solution to the dispute had been struck because the inquiring British administrator had exercised reason and foresight while invoking the ITBSO. But it could also be inferred that the settlement was satisfactory to all perhaps because the contested territory was communal land, or perhaps because these villages might have been compelled to compromise in order to put up a common front against Bali-Nyonga with whom they, as part of the Widikum ethnic group, had an even bigger land dispute. This, notwithstanding, many of the disputes resolved by the British ensued in peace, which lasted up until the end of British rule. This contrasts sharply to resolution modalities of independent Cameroon administrations that hinge essentially on the use of force and coercion.

\section{Land/boundary dispute resolution in post-colonial Bamenda}

Despite its successes, use of the ITBSO in resolving boundary disputes was gradually discontinued from 1952 to the end of British colonial rule in 1961 because of disagreements between administrators and lawyers over its interpretation (Secretary, Eastern Provinces 1951). Upon attainment of 


\section{Attempts to resolve land/boundary disputes in Bamenda, Cameroon}

independence the defunct West Cameroon Government established the InterCommunity Boundaries Settlement Law (ICBSL) in 1962 to resolve boundary disputes in Bamenda. Under the provisions of the ICBSL, disputes were referred to a boundary tribunal composed of a chairman and four members who conducted inquiries by 'hearing evidence' from members of villages contesting land (File No. Qf/a (1) 1964:13). Functioning essentially like the ITBSO, the ICBSL was effective and its judgments were rarely challenged (File No. Qf/a (1) 1964:13). Reunification of former British and French Cameroons in 1972 brought this approach to settling land/boundary disputes to an end. In its place was established Land Consultative Boards at various levels, national, provincial, divisional, and sub-divisional, to settle land disputes. The decisions of the different boards have to be ratified by the Ministry of Territorial Administration, a process that takes years (Diymba 1997).

The establishment of Land Consultative Boards was basically theoretical. In practice, the Boards do little and the little they do is poorly done. Administrators have frequently intervened in disputes without consulting board members; at other times, they have flouted decisions reached by boards (Mukong 1997b). Usually it takes days, sometimes weeks for administrators to intervene in land/boundary disputes, and only when the situation has gone out of control, necessitating the deployment of troops to restore order. These soldiers inflict added casualties during their deployment, as was the case during the BaliNyonga-Chomba land/boundary hostility of May 15, 1995 (Mukong 1997a:1). Even when there is evidence of an imminent confrontation, administrators do little to pre-empt it. Again, the example of Bali-Nyonga and Chomba is a case in point; although the chief of Bali-Nyonga had informed the DO for Mezam of an eminent confrontation, no remedial action was taken (Mukong 1997a:1).

Measures taken by administrators to resolve disputes are implemented 'piecemeal', occasioning their reoccurrence, and their decisions are 'not based on facts but ... on the bargaining power of the belligerents. Even when a judicious decision is taken by one administrator, his successor may scrap it away ...' (Mukong 1997a:1). Moreover, many a post-colonial administrator posted to the region is French-speaking. They lack the knowledge of the history of the numerous 


\section{Emmanuel M. Mbah}

disputes and make no attempt to acquaint themselves with these. This explains why they frequently resort to punitive methods of conflict management.

Finally, Government decrees that override colonial boundary settlements have inflamed already settled disputes in some areas. For example, post-1977 BaliNyonga/Widikum confrontations have been caused by the Ahidjo decrees of 1977 and 1982, which, in essence, abrogated settled colonial boundaries in favour of the Widikums, and without compensation to Bali-Nyonga. These confrontations would have been avoided had those decrees not been promulgated and enforced in the first place, or had government taken steps to dialogue with Bali-Nyonga to make sure they received compensation for lost land. Dialogue needs to be the Government's first option in any resolution attempt.

\section{Conclusion}

By re-defining pre-colonial notions of political and physical space, European colonialism established a new dispensation and interpretation of belonging in the Grasslands of Bamenda. It altered pre-colonial structures of economic opportunity by giving undue advantage to particular communities, the result of which was an unprecedented wave of identity consciousness among and between village-groups, as well as a redefinition of the limits of their hitherto geographical confines (Mustapha 1998:38-39). But while the British made a serious attempt to resolve these disputes through the ITBSO, the Government of Cameroon has failed to follow through. Because of this failure village-groups have decided to revisit previous boundary resolutions for political and economic reasons. Solutions to these disputes can only be reached if Government decides in good faith, and using meaningful dialogue, to examine the economic plight of the people. Peace initiatives that consider economic stimulus plans which include compensation for communities dispossessed of land would gradually sway groups in the region from a land-based subsistence, and would go a long way to reduce their reliance on it. 


\section{Attempts to resolve land/boundary disputes in Bamenda, Cameroon}

\section{Sources}

Chem-Langhee, Bongfen 1983. The origins of the Southern Cameroons House of Chiefs. The International Journal of African Historical Studies, 16 (4), pp. 653-673. Available from: $<$ http://links.jstor.org/> [Accessed 14 March 2008].

Chilver, E.M. 1966. Zintgraff's explorations in Bamenda, Adamawa and Benue lands 1889-1892. Buea, Government Printer.

Chilver, E.M. and P.M. Kaberry 1968. Traditional Bamenda: The precolonial history and ethnography of the Bamenda Grassfields. Buea, Government Printer.

Colonial Office 1956. Cameroons under United Kingdom Administration: Report for the Year 1955. London, Her Majesty's Stationery Office (published for the Colonial Office).

Diymba, Charles 1997. Interview, Governor's Office Bamenda, 31 October 1997.

Ekeh, Raphael Chima 1999. Aguleri-Umuleri conflict - The theatre of fratricidal war. In: Mekenkamp, Monique; Paul van Tongeren and Hans van de Veen eds. Searching for Peace in Africa: An overview of conflict prevention and management activities. Utrecht, European Platform for Conflict Prevention and Transformation.

Fanso, Verkijika G. 1982. Trans-Frontier relations and resistance to Cameroon-Nigeria colonial boundaries 1916-1945. Doctorat D’État thesis, University of Yaoundé, Yaoundé.

File No. Ab 5 1925. Buea, National Archives.

File No. C 64 Qf/a (1) 1933 (23 December). Inter-tribal boundaries settlement ordinance. Buea: National Archives.

File No. Qf/a (1) 1964. Land Tenure in West Cameroon. Buea, National Archives.

File No. 734 Qf/b (2) 1943 (9 September). Bali-Bamengen land disputes, Bamenda Division. Buea, National Archives.

File No. 1130, Qf/f (1) 1950. Mukuru-Nkoromanjang land dispute: Boundary dispute, Babadji village versus Okoremanjang. Buea, National Archives.

File No. 1828 Qf/b (1) 1936. Bambunji-Babujang village groups, Bamenda Division, Boundary dispute. Buea, National Archives.

File No. 2124 Qf/b (2) 1939. Bangangu-Bambetu land dispute, Bamenda Division. Buea, National Archives.

File No. 2341 Qf/b (1) 1938. Bande-Bangwa boundary dispute, Bamenda Division. Buea, National Archives.

File No. 4848 Qf/b (3) 1933. Bali-Bamengen (Mengen) land dispute, Bamenda Division. Buea, National Archives.

File No. 9570 Qf/b (1) 1943. Bali-Guzang (Babujang) boundary, Bamenda Division, Cameroons Province. Buea, National Archives.

File No. 22411 Qf/b (1) 1948. Land dispute [between] Bafanji and Bali Gashu. Buea, National Archives. 


\section{Emmanuel M. Mbah}

Gluckman, Max 1965. Politics, law and ritual in tribal society. Oxford, Basil Blackwell.

Gonnin, Gilbert 1998. Ethnicity, politics and national awareness in Côte d'Ivoire. In: Nnoli 1998.

Hunt, W.E. (DO) 1924. An assessment report on the Bali clan in the Bamenda Division of the Cameroons Province. File No. Ab 5, 1925. Buea, National Archives.

Kwai, Joshua (Programme Coordinator for the Ecumenical Youth Peace Initiative Commission, EYPIC) 1997. Interview, Bamenda, 27 October 1997.

Lawrence, T.G. 1950. To the Resident, Ogoja Province, Ogoja: No. 8666/404: Inter-Tribal Boundaries Settlement Ordinance No. 49 of 1933. (From Bamenda: Provincial Office, Bamenda, 24 March 1950, to Eastern Provinces: Secretary's Office, Enugu, 12 April 1950.) In File No. 1608 Qf/b (2) 1950, Inter-Tribal Boundaries Settlement Ordinance No. 49 of 1933. Buea, National Archives.

Mbah, Emmanuel Mbah 1994. The Bali Nyonga-Meta conflict 1884-1961. M.A. thesis, University of Yaoundé 1, Yaoundé.

Mukong, Albert W. 1997a. Tribal Conflicts in the North West Province. Bamenda, Human Rights Defence Group Collections.

Mukong, Albert W. 1997b. Interview, Human Rights Defence Group Head Office, Bamenda, 30 October 1997.

Mustapha, Abdul Raufu 1998. Identity boundaries, ethnicity and national integration in Nigeria. In: Nnoli 1998.

Niba, Mathias L. 2007. Bafut under colonial administration 1900-1949. Available from: $<$ http://lucy.ukc.ac.uk/Chilver/Paideuma/paideuma-Introdu-4.html> [Accessed 29 October 2007].

Nkematabong, Martin 2007. Bali/Bawock crisis: Medics pre-empt epidemic outbreak! Cameroon Tribune, Yaoundé, 26 March 2007. Available from: $<$ http://www.cameroon-info.net/cmi_show_news.php> [Accessed 14 December 2007].

Nnoli, Okwudiba ed. 1998. Ethnic Conflicts in Africa. CODESRIA Book Series. Dakar, CODESRIA.

Secretary, Eastern Provinces 1951. To the [Honourable] the Chief Secretary to the Government, Lagos. No. 8666/422: Inter Tribal Boundaries Settlement. (From Eastern Provinces: Secretary's Office, Enugu, 13 March 1951, to Bamenda: Provincial Office, Bamenda, 24 March 1950.) In File No. 1608 Qf/b (2) 1950[-55]. Inter-Tribal Boundaries Settlement Ordinance No. 49 of 1933. Buea, National Archives.

Senior District Officer, Bamenda 1941. Interim Report on the Bororo-Pagan Boundaries Demarcation, Bamenda Division, Cameroons Province. In File No. B. 3152, NW/Qg/a. 1941/1, Bororo Grazing Rights: Correspondence Concern (sic). Bamenda, 1941. Bamenda, North-West Provincial Archives Bamenda.

Tangwa, Joseph Fover 1993. Note to His Excellency the Governor: Bambili/Babanki Tungoh boundary dispute. In File No. GNW/54, 9 July 1993, Governor's Office Bamenda. 